\title{
An analysis of the long-term variation in stream water quality for three upland catchments at Loch Dee (Galloway, S.W. Scotland) under contrasting land management
}

\author{
S.J. Langan ${ }^{1}$ and D. Hirst ${ }^{2}$ \\ ${ }^{1}$ Macaulay Land Use Research Institute, Craigiebuckler, Aberdeen, Scotland, AB15 8QH, UK \\ ${ }^{2}$ Norwegian Computing Centre, P.O. Box 114, Blindern, N-0414 Oslo, Norway \\ Email for corresponding author: s.langan@macaulay.ac.uk
}

\begin{abstract}
A long term record of water chemistry, consisting of twenty years of weekly spot samples, from three sub-catchments draining into a loch and the loch outflow in Galloway, S.W. Scotland have been analysed. The analysis undertaken consisted of a three component statistical trend model. The technique allows the identification of long-term, seasonal and short-term trends, as well as differentiation between base flow and high flow responses. The land usage in the three sub-catchments is moorland, forest and forest plus lime. The results show that, since the mid1980 s, there has been a gradual decline in stream-water sulphate of the same order as reductions in the deposition of non-marine sulphate. Superimposed on this trend are somewhat random but considerable perturbations to this decline, caused by sea-salt deposition. There is no evidence of changes in surface water nitrate concentrations. The influence of different land management is evident in the sulphate, nitrate and $\mathrm{pH}$ data, whilst variations in calcium concentrations are also a product of differences in hydrological routing and the impact of sea-salt episodes.
\end{abstract}

Keywords: trend analysis, acid deposition, land management, water quality, sea-salts, Galloway, S.W. Scotland.

\section{Introduction}

The role of atmospheric inputs, both natural and pollutant, in determining water quality in upland catchments has been recognised since the work and reviews of Crisp (1966) and Cryer (1976), which assessed the influence of atmospheric inputs on surface water chemistry. In the early 1980s, upland catchment research focussed on the concerns associated with the impact of acid deposition on the acidification of soils and freshwaters. This concern led to the establishment of a range of small catchments monitored under differing environmental conditions across Europe and N. America. A review of many of these studies has been undertaken by Hornung et al., (1991) and Moldan and Cerny (1994). The data and analysis undertaken in many of these studies showed that stream-water quality in catchments with acid sensitive geology and overlain by base-poor acidic soils reflects the impact of atmospheric inputs. Typically changes in stream-water chemical characteristics such as the major cations, anions, alkalinity and aluminium are associated with changes attributable to the impact of acid deposition. Moreover, stream-water sulphate concentrations were linearly related to atmospheric inputs of non-marine sulphate. However, a complicating factor in assessing the role of acid deposition at some of the sites, particularly those in the coastal regions, has been the influence of episodic incursions of marine sea-salts (Skartveit, 1981; Langan, 1989). These authors showed that following large atmospheric fluxes of sea-salts to catchments, soil exchange processes resulted in a rapid leaching of hydrogen ions from soils with consequent acidification of surface waters during storm events. This process occurs across a range of catchments in western Europe, (Davies et al., 1992) particularly, Norway (Wright et al., 1988), Scotland (Langan, 1989) and Ireland (Farrell, 1995). Neal et al., (1997a,b) for determinands in which concentrations are strongly influenced by hydrological routing, suggest a separation of the component chemistry derived from groundwater as distinct from soil water components provides 
a useful framework for viewing surface water chemistry. However, the system under study is highly complex and heterogeneous (Neal, 2004).

At the same time as evidence was accumulating on the role acid deposition may have on water quality, there were suggestions that soil and surface water acidification could be exacerbated by different land management practices (Harriman and Morrison, 1982) and, in particular, the scavenging capacity for atmospheric pollutants of coniferous afforestation (Fowler et al., 1989) and the uptake of soil nutrients (Forestry Commission, 1991; Reynolds and Edwards, 1995). Neal et al., (2001) show for a site in midWales that the major differences in water quality from adjacent catchments under moorland and forest occurred with the onset of clear felling which gave rise to increased stream concentrations of nitrate and aluminium while Neal et al. $(1998 \mathrm{a}, \mathrm{b})$ considered forestry and acidification in a regional context based on regional monitoring studies. Helliwell et al., (2001) suggested that waters draining forested catchments in S.W. Scotland were more acidic than moorland catchments and that declining emissions of sulphur had not led to a recovery in afforested streams. Neal et al. (1998a) showed in the case of deforestation that acidification of streams due to nitrate release was often of second order importance due to a variety of compensating mechanisms.

With recent reductions in European emissions of sulphur dioxide, scientific research has centred on the degree to which soils and surface waters may recover in the light of declining atmospheric inputs, at least of sulphur (Ferrier $e t$ al., 2001, 2003). The immediate effect has been increases in Acid Neutralising Capacity, but recovery in alkalinity, $\mathrm{pH}$ and Aluminium show a much smaller response. Evans et al., (2001) document that recovery across Europe shows a strong geographical and spatial pattern: it is the weakest in Germany, strongest in the Czech Republic and moderate in Scandinavia and the UK. Within Scotland, acidification of surface waters is viewed as major pressure on the water quality of upland areas (SEPA, 2000; Langan et al., 2001). In a modelling study, Jenkins et al. (2003) suggest that predictions to 2016 show, with the exception of Central England, that other acid sensitive areas of the UK will show a recovery of surface waters from acidification.

This paper presents analysis of a hydrochemical data set to identify the contrasting response of three inflowing streams to an upland loch and the outflow from the loch. Differences in water quality are analysed according to the differences between sub-catchment land uses and temporal trends (yearly, seasonal and episodic) over 20 years of record, 1981-2000.

\section{Study area and data collection}

To enhance the understanding of the effect of acid deposition and upland land management on surface water quality, a long-term catchment study was established at Loch Dee, S.W. Scotland. The Loch Dee Project was established in 1979 as a joint venture between the Solway River Purification Board (subsequently part of Scottish Environment Protection Agency), the Forestry Commission and the Freshwater Fisheries Laboratory, Pitlochry.

\section{GENERAL SETTING}

Loch Dee is situated in the Galloway Hills of south-west Scotland (national grid reference NX 470 790). The catchment consists of three distinct sub-catchments that flow into the loch. The total catchment area to the loch outflow is $15.6 \mathrm{~km}^{2}$ and the surface area of the loch is $1 \mathrm{~km}^{2}$. Catchment altitude ranges from $716 \mathrm{~m}$ to $216 \mathrm{~m}$ at the loch outflow. Precipitation inputs to the catchment are of the order of 2000-2500 $\mathrm{mm}$ per year. Acid inputs from the atmosphere in the period 1986-1988 were in excess of $25 \mathrm{~kg} \mathrm{~S} \mathrm{ha}^{-1} \mathrm{yr}^{-1}$, whereas contemporary deposition is of the order of $9-12 \mathrm{~kg}$ $\mathrm{S} \mathrm{ha}^{-1} \mathrm{yr}^{-1}$ (DEFRA, 2001).

The three distinct sub-catchments which flow into Loch Dee are: the Green Burn $\left(2.5 \mathrm{~km}^{2}\right)$, the White Laggan $\left(5.68 \mathrm{~km}^{2}\right)$ and Dargall Lane $\left(2.1 \mathrm{~km}^{2}\right)$. Summary details of the catchment and management practices are given in Fig. 1 and Table 1 . Approximately $70 \%$ of the Green Burn subcatchment was planted between 1973 and 1976, predominantly with Sitka spruce (Picea sitchenis) and smaller areas of Lodgepole pine (Pinus contorta). The productivity of the trees in the catchment is poor (yield class 10) compared to other forests in the Galloway region (yield class 16). In $197530 \%$ of the White Laggan was planted with Sitka spruce. This sub-catchment has also been used in various experimental management exercises, comprising different lime applications, to ameliorate surface water acidification (Table 1). The Dargall Lane sub-catchment is the control, with no change in land use (semi-natural moorland) and limited management. The monitoring of these three sub-catchments together with the loch outflow form the basis of the project.

The catchment is typical of much of upland Scotland, comprising part of a glaciated valley with steep upper slopes leading down to a broad valley floor. The natural vegetation of the catchment is heather moor (Calluna vulgaris) and acid grassland (Deschampsia flexuosa). The soils of the catchment range from rankers and peaty podzols on the upper slopes with some peaty gleys on the lower slopes and peat on the valley floor. The soil parent materials and the underlying geology comprise predominantly granite 


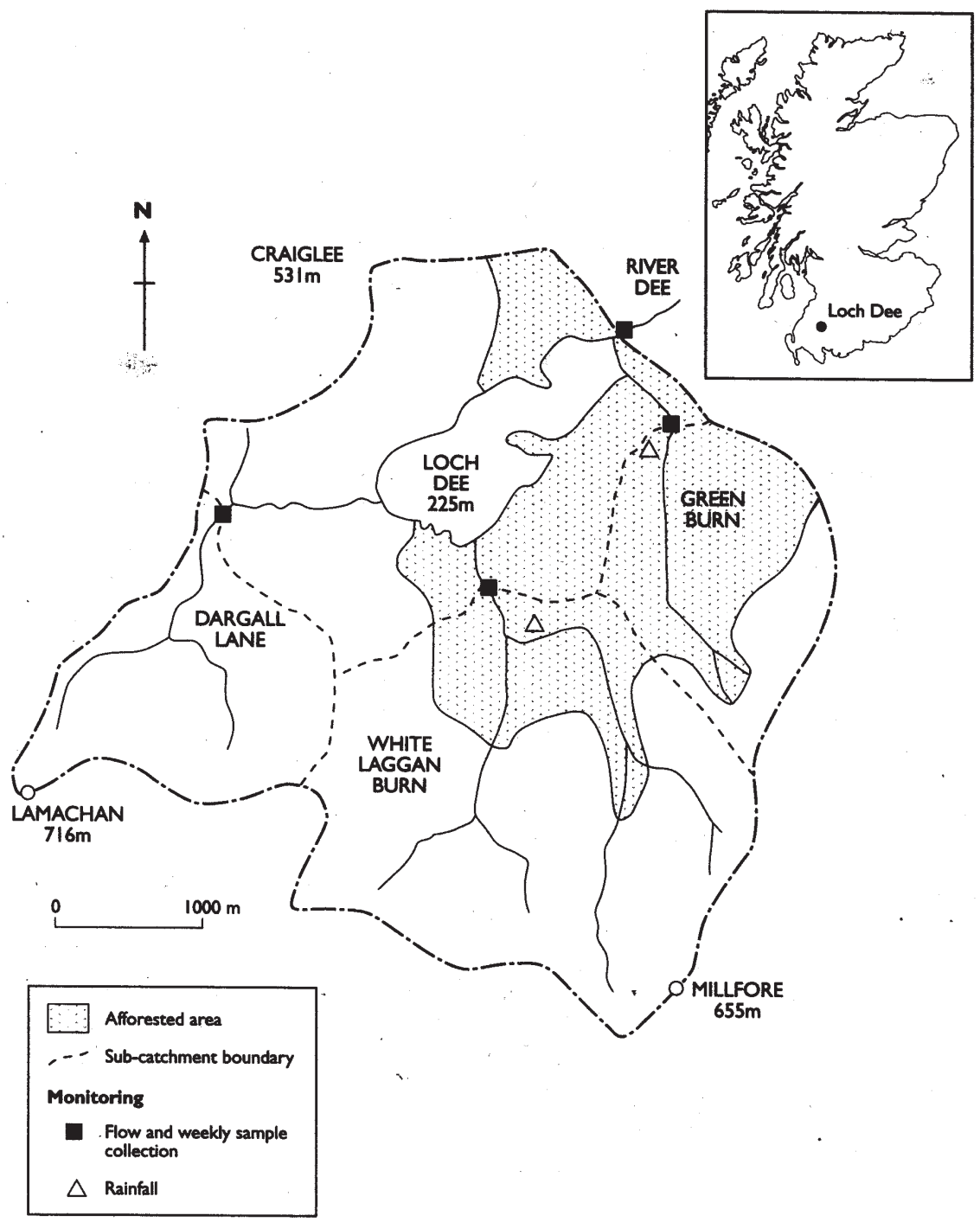

Fig. 1. General setting and monitoring programme at Loch Dee

(Countesswells, Dalbeattie, Priestlaw Association) although the upper parts of the catchment are underlain by metamorphosed greywackes (Ettrick Association). Both of these rock-soil type assemblages have been recognised as sensitive to acidification due to their slow weathering and release of base cations (Langan and Wilson, 1994).

\section{THE MONITORING AND SAMPLING PROGRAMME}

From early 1980, weekly spot samples have been taken at the three feeder sub-catchments and loch outflow. In addition, weekly bulk precipitation samples have been collected from the catchment. These samples are returned to the SEPA laboratories in Dumfries on the day of collection where they are refrigerated until analysis. Samples are analysed for all major cations and anions, following standard analytical methods for surface waters (Lees, 1992). Other details of the catchment and monitoring programme can be found in Burns et al. (1984), Tervet and Harriman, (1988), Langan (1989), Farley and Werritty (1989) and Grieve (1990).

\section{The data record and method of analysis}

\section{DATA RECORD}

Weekly samples for the period January 1981 to December 2000 have been used in the analysis of spatial and temporal variation in the water quality. To overcome some initial limitations of the data, particularly in the earlier part of the record, the following assumptions and manipulation of the data were undertaken: 
Table 1. Site Details of Loch Dee.

\begin{tabular}{|c|c|c|c|c|c|}
\hline Catchment & Description & $\begin{array}{l}\text { Area } \\
\left(\mathrm{km}^{2}\right)\end{array}$ & $\begin{array}{l}\text { Affores- } \\
\text { tation }\end{array}$ & $\begin{array}{l}\text { Vegetation } \\
\text { species }\end{array}$ & $\begin{array}{l}\text { Treatment } \\
\text { Mar } 1980\end{array}$ \\
\hline $\begin{array}{l}\text { Dargall } \\
\text { Lane }\end{array}$ & $\begin{array}{l}\text { Upper part of catchment steep sided corrie } \\
\text { forming armchair hollow. Soils of peaty } \\
\text { rankers, peaty podzols and peats. Standing } \\
\text { surface water in boggy hollows. Channel is } \\
\text { incised into peat. Channel bed is armoured by } \\
\text { rocks and boulders. }\end{array}$ & 2.1 & $0 \%$ & $\begin{array}{l}\text { Sphagnum (sp.) } \\
\text { Calluna vulgaris } \\
\text { Gramineae }\end{array}$ & $5 \mathrm{t}$ scallop shells at road bridge \\
\hline $\begin{array}{l}\text { White } \\
\text { Laggan }\end{array}$ & $\begin{array}{l}\text { Broad upper valley, rock outcrops are common. } 5 \\
\text { Uppermost part of catchment-moor/rough } \\
\text { pasture, lower area-forested, although incomplete } \\
\text { canopy. Planted } 1975 \text {. Soils dominted by peaty } \\
\text { podzols. Channel cut in peat and alluvium in } \\
\text { lower reaches. 'Buffer zone' flanks major water } \\
\text { course. }\end{array}$ & 5.7 & $30 \%$ & $\begin{array}{l}\text { In addition to } \\
\text { above: } \\
\text { Picea sitchensis } \\
\text { Pinus contorta } \\
\text { Buffer zone: } \\
\text { Sorbus salix } \\
\text { Betula alnus }\end{array}$ & $\begin{array}{l}\text { Mar } 19805 \mathrm{t} \text { scallop shells at } \\
\text { road bridge } \\
\text { Oct } 19805 \mathrm{t} \text { scallop shells as } \\
\text { road bridge } \\
\text { Mar } 198158.2 \mathrm{t} \text { limestone } \\
\text { powder } \\
\text { Oct } 198020.4 \mathrm{t} \text { limestone chips } \\
\text { Jan } 1982 \quad 19.6 \mathrm{t} \\
\text { Feb } 1982 \quad 20.7 \mathrm{t} \\
\text { Apr } 198356.5 \mathrm{t} \text { limestone } \\
\text { powder }\end{array}$ \\
\hline $\begin{array}{l}\text { Green } \\
\text { Burn }\end{array}$ & $\begin{array}{l}\text { Gently sloping catchment forested in all but } \\
\text { highest altitudes. Planted 1973-75, canopy still } \\
\text { incomplete. Catchment drainage dominated by } \\
\text { forest drains. Soils are peaty podzol although peat } \\
\text { occurs more extensively in lower catchment. } \\
\text { Some parts of channel in bedrock, otherwise in } \\
\text { peat and alluvium }\end{array}$ & 2.5 & $70 \%$ & $\begin{array}{l}\text { Picea sitchensis } \\
\text { Pinus contorta }\end{array}$ & $\begin{array}{l}\text { Sep } 1982 \text { PK fertiliser over } \\
3.99 \mathrm{~km}^{2} \\
\text { Green Burn and upper area of } \\
\text { White Laggan }\end{array}$ \\
\hline
\end{tabular}

(i) In the absence of flow data for the Dargall Lane and Green Burn sub-catchments (pre-1983) the flow weighting of the data for these sites is based on a regression relationship from the measured flow at the White Laggan. These estimated flows were provided by the local SEPA hydrologists.

(ii) Pre 1984 Nitrogen data were reported as total oxidised nitrogen (TON): after this date they were reported as nitrate, so it has been assumed that all of TON occurs as nitrate.

(iii) The authors are aware of changes in the method of analysis for sulphate between 1981-1983 and recorded concentrations were lower than might otherwise have been expected. Hence, this early sulphate data record have not been included in the analysis. After 1984, ion chromatography has been used for all analyses. Similarly post 1998, after a change in laboratory and method of determination, the sulphate data became highly irregular and have been excluded from the trend analysis. In compiling the data, it also became evident that changes in the undertaking, determination and reporting of alkalinity have varied through the data record. Whilst recognising the importance of alkalinity as a parameter in indicating acidification status, the authors decided to exclude the data because of the uncertainty in detecting a trend due to environmental change as opposed to one introduced through determination and analysis.

\section{TREND ANALYSIS OF WATER QUALITY DATA}

In terms of the available data, the determinands of greatest interest for changing water quality in the uplands as a result of atmospheric deposition and land-use change are calcium, the major anions (sulphate, nitrate and chloride) and $\mathrm{pH}$. One of the principal difficulties in interpreting such environmental data sets is separating trends from natural variations in the data. Using additive models it is possible 
to examine the variation in water quality due to changes in flow, seasonality and long term trends. Similar approaches have been described elsewhere (Robson and Neal, 1996; Hirst, 1998; Miller and Hirst, 1998). The model used here is a time series model with three components; trend, variable amplitude seasonality and variable slope flow. The form of the model is:

$$
\begin{gathered}
\log (\text { determinand })=\text { baseline }+a \times \log (\text { flow }) \\
+b \times \text { season }+ \text { resid }
\end{gathered}
$$

( $\mathrm{pH}$ is not logged)

in which baseline is an autocorrelated time series:

$$
\operatorname{baseline}(t)=\operatorname{baseline}(t-1)+u
$$

Here $t$ is time in days. The variance of the independent Gaussian error term $u$ determines the smoothness of the trend.

The relationship with $\log ($ flow $)$ is determined by the regression coefficient $a$, which is allowed to vary in time in a similar way to the trend, i.e. $a(t)=a(t-1)+v$, where $v$ is another independent Gaussian term. The ratio of the variances of $u$ to $v$ is fixed at 50:1. This ensures that the trend picks up long term changes, while the relationship with flow is allowed to vary more quickly (in particular it can vary within a year). $\log ($ flow $)$ is corrected to have zero mean so the trend can be interpreted as the log concentration at mean flow.

The seasonality is modelled by the sine curve season, with the amplitude $b$ allowed to vary in time: $b(t)=b(t-1)+w$, $w$ is independent Gaussian noise with variance equal to that of $v$; resid is another independent Gaussian noise term.

The parameters are fitted by maximum likelihood using the Kalman filter.

The trend results from the analysis can be interpreted as the concentration that would be achieved at any time, if the flow were at its mean value. It is therefore a 'flow adjusted concentration', which removes the effect of wet and dry periods. This has the advantage that trends at flows other than the mean can be investigated. Because the flow relationship varies, trends at high and low flow can be very different. This can be seen by predicting concentrations at, e.g. 5 and 95 percentile flow. A similar methodology can be found in Hirst (1998) and Potts et al. (2003).

\section{Results}

Table 2 details the inter-annual variation in bulk precipitation collected in the catchment between 1981-1999. The salient features of the data are the increase in the $\mathrm{pH}$ over the last

Table 2. Annual mean bulk precipitation concentrations based on weekly data at Loch Dee (units ueq $1^{-1}$, NA- not available, * incomplete year no data August to December).

\begin{tabular}{llllll}
\hline Year & $p H$ & $\mathrm{Ca}$ & $\mathrm{SO}_{4}$ & $\mathrm{NO}$ & $\mathrm{Cl}$ \\
\hline 1981 & 4.7 & 16 & 48 & 16 & 106 \\
1982 & $\mathrm{NA}$ & $\mathrm{NA}$ & $\mathrm{NA}$ & $\mathrm{NA}$ & $\mathrm{NA}$ \\
1983 & 4.9 & 18 & 65 & 16 & 207 \\
1984 & 4.7 & 15 & 56 & 19 & 187 \\
1985 & 4.8 & 13 & 51 & 15 & 100 \\
1986 & 4.5 & 10 & 47 & 14 & 152 \\
1987 & 4.6 & 9 & 41 & 19 & 66 \\
1988 & 4.7 & 11 & 52 & 18 & 159 \\
1989 & 4.8 & 9 & 39 & 14 & 159 \\
1990 & 4.8 & 11 & 43 & 14 & 173 \\
1991 & 4.7 & 10 & 42 & 16 & 144 \\
1992 & 4.8 & 11 & 37 & 15 & 96 \\
1993 & 4.7 & 9 & 38 & 19 & 89 \\
1994 & 4.8 & 11 & 36 & 18 & 106 \\
1995 & 4.9 & 14 & 37 & 37 & 121 \\
1996 & 4.7 & 10 & 47 & 22 & 106 \\
1997 & 5 & 12 & 31 & 14 & 123 \\
1998 & 5 & 23 & 30 & 13 & 102 \\
1999 & 5.2 & 19 & 34 & 13 & 138 \\
$2000^{*}$ & $\mathrm{NA}$ & 10 & 35 & 18 & 101 \\
\hline
\end{tabular}


three years of the record, the decreasing concentration of sulphate since the late 1980s and early 1990s and the large annual variation in chloride inputs. It is against this background that the variation in the water chemistry of the streams and loch outflow at Loch Dee are modelled and examined in more detail with specific reference to the role of land management.

Table 2 summarises water quality in terms of annual flow weighted minimum, mean and maximum concentrations for each site. Results of the modelling of the water quality parameters of $\mathrm{pH}$, calcium, nitrate, sulphate and chloride are in Table 4 for each of the catchment sites and determinands.

\section{$\mathrm{pH}$}

The annual mean $\mathrm{pH}$ at the White Laggan (with the exception of 1993) is always greater than 6.0 and higher than the other sites (Table 3a). Annual pH at the Dargall Lane has the lowest inter-annual range, between 5.2 and 5.8 (Table 3b). Green Burn demonstrates the largest range in $\mathrm{pH}$ within individual years. $\mathrm{pH}$ at the loch outflow follows the same annual pattern as the streams and is closest to that of Green Burn, although slightly more acidic. This is shown graphically in Fig. 2 from which the damped response of the loch outflow compared to the three inflowing streams is evident. Figure 2 also suggests some improvement in the minimum $\mathrm{pH}$ associated with low flows over the latter part of the record. From the trend analysis, Table 4 suggests the variance in the $\mathrm{pH}$ data is most strongly influenced by flow. The degree to which the percentage variance accounted for by the change in flow across the catchments reflects differences in the hydrolological responses of the catchments; hence, the variance from the loch is lower as the loch level rises and falls, damping the response at the outflow. There is little longer term trend in the $\mathrm{pH}$ data and the seasonality in the data largely reflects seasonal differences in flow. The results from the trend analysis are presented graphically in Fig. 3 for overall trend and high and low flow component trends of the fitted model (1). The results show significant subcatchment differences. With the exception of a perturbation in 1985 , there is little or no trend over time in the overall data (Fig. 3a). The data representing high flow conditions (Fig. $3 \mathrm{~b}$ ) suggest a separation of the sub-catchments with White Laggan maintaining the highest $\mathrm{pH}$ and Dargall Lane and Green Burn having the lowest $\mathrm{pH}$ pre the mid-1990s. However after 1996, Dargall Lane indicates an increase in $\mathrm{pH}$ and, from then, Green Burn shows the lowest pH. A similar change in $\mathrm{pH}$ is observed in the White Laggan data. The loch outflow is intermediary to the inflow stream responses. During low flow conditions (Fig. 3c), the Dargall
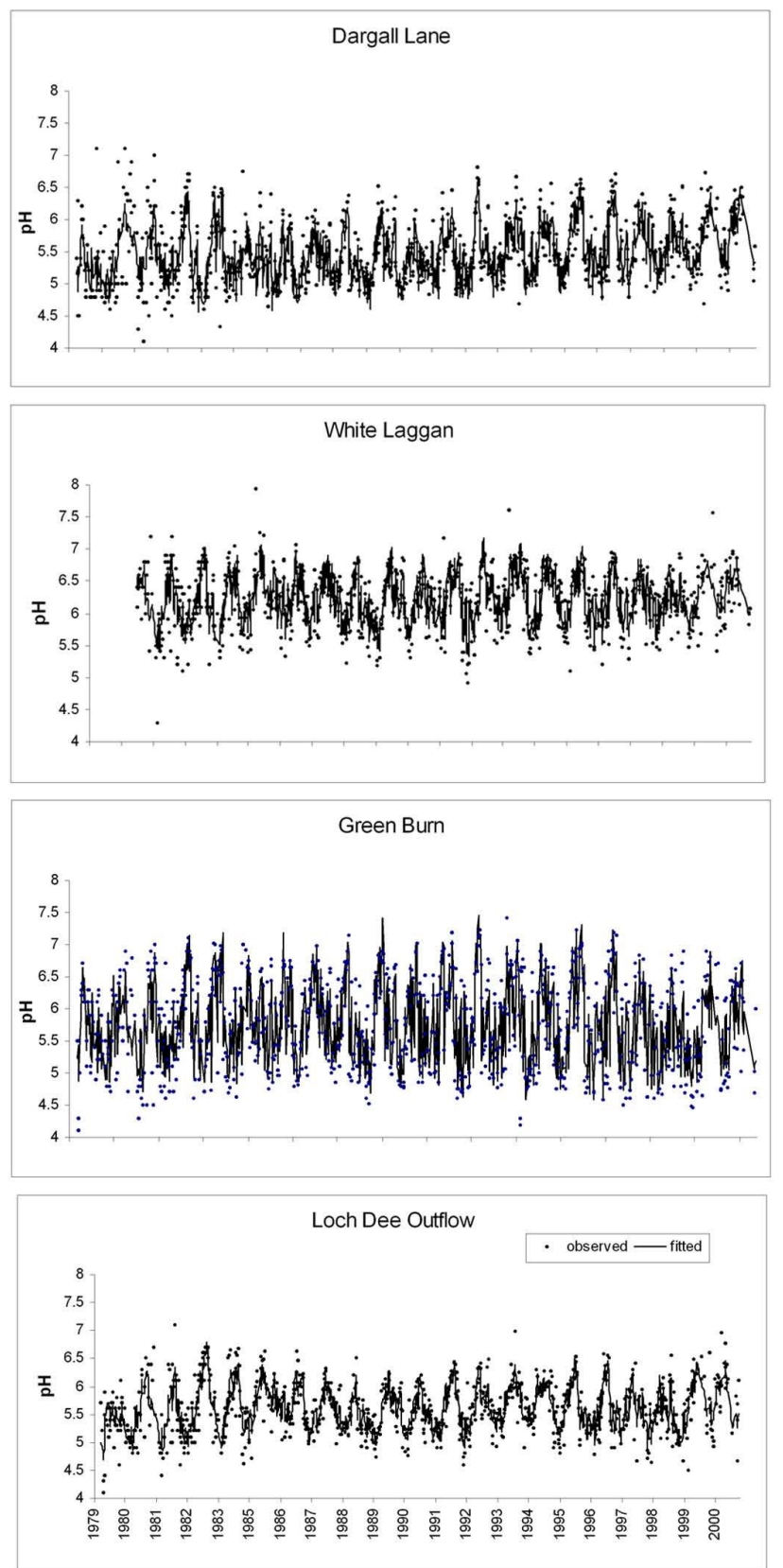

Fig. 2. Observed versus modelled $\mathrm{pH}$ data for the three inlet streams and loch outflow.

Lane and Loch outflow show the lowest $\mathrm{pH}$, although from 1996 this suggests an increase. The White Laggan and Green Burn data demonstrate higher low flow $\mathrm{pH}$. In contrast to Dargall Lane and the loch outflow the trend in $\mathrm{pH}$ with time has been an initial increase and, latterly, a decline. This is reflected in the trend variance data in Table 4

\section{CALCIUM}

As with $\mathrm{pH}$, the concentrations of calcium are consistently 


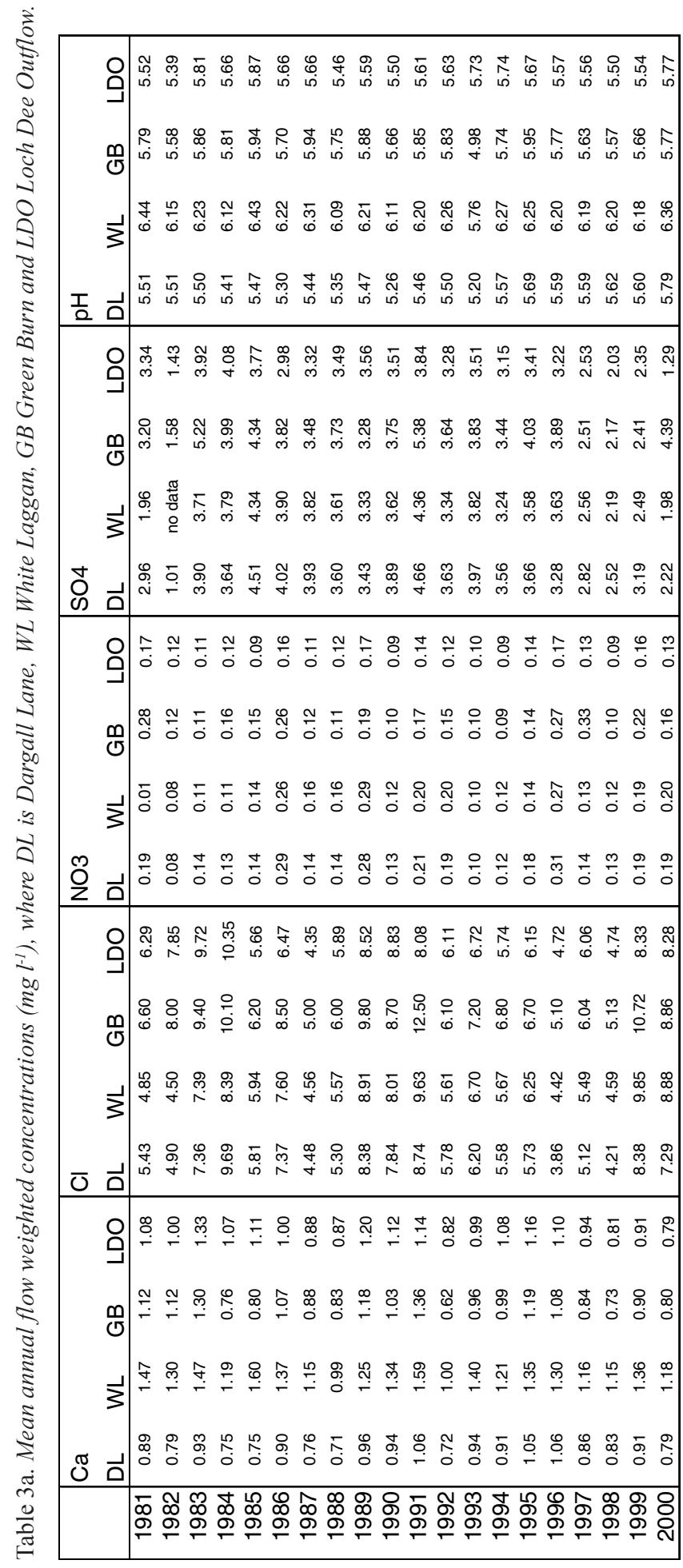

higher in the White Laggan than in the other sub-catchments and the loch outflow. The Dargall Lane has the lowest calcium concentration (Table 3 and Fig. 4). The loch outflow has similar mean concentrations but variations are larger than those of Dargall Lane. Over the early part of the record

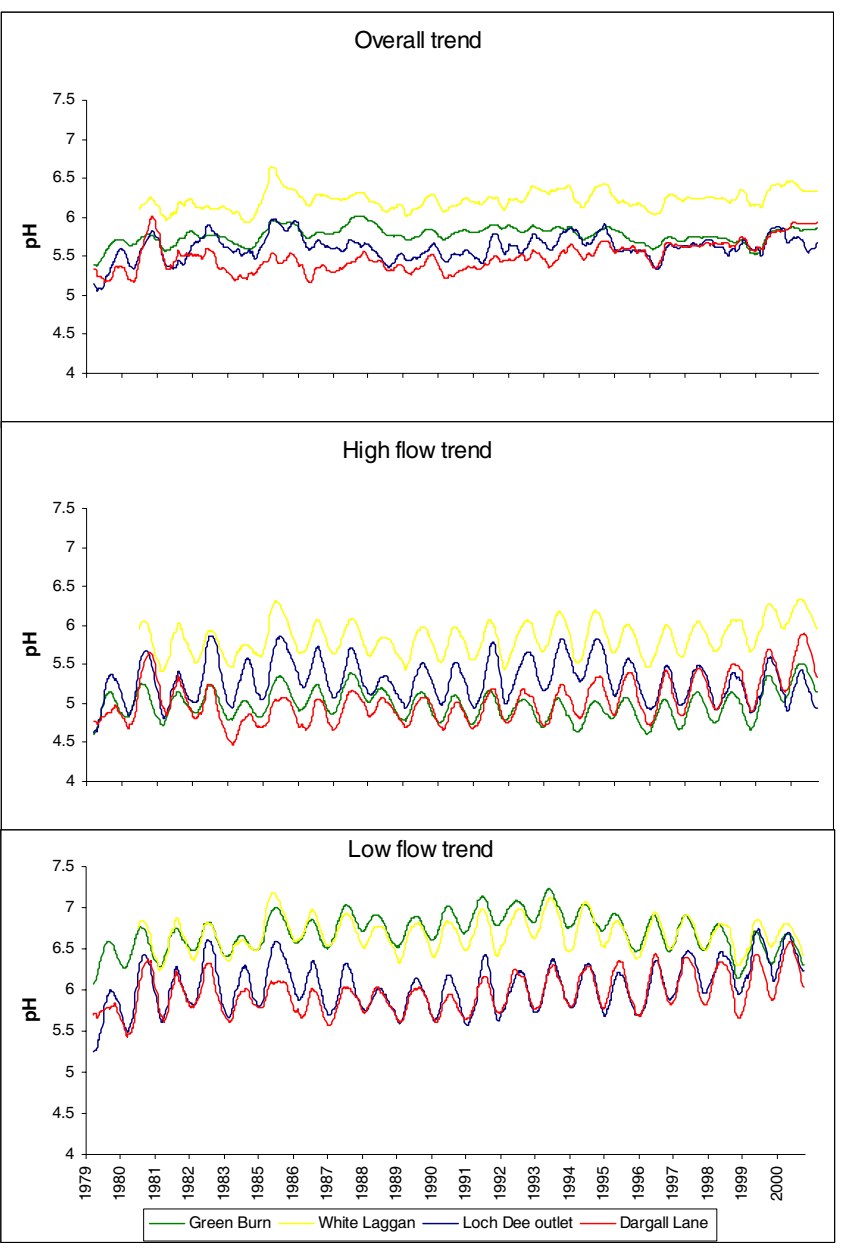

Fig. 3. Trend analysis for pH using: a) all data b) high flow and c) low flow data (for the three inlet streams and loch outflow)

(pre-1989) the maximum concentrations in the White Laggan are noticeably higher than in the other tributaries and the outflow, because of the experimental liming programme (Table 1). Over the latter part of the record the difference in maximum concentrations between the White Laggan and other monitoring points is diminished significantly. In 1994, the maximum concentrations occur in the Green Burn and the loch outflow. These catchment differences are amplified by considering the results from the trend analysis. Table 4 indicates the degree to which the analysis accounts for the variation in calcium concentration due to flow. Figure 5 illustrates the trend analysis examined for different flow regimes. The results show that calcium concentrations have a downward trend over the record, particularly in Green Burn and White Laggan. This is most marked in the overall data and during low flows (Table 4 and Fig. 5c). Superimposed on the overall declining trend are undulations giving rise to smaller increases in 


\begin{tabular}{|c|c|}
\hline$\frac{\mathrm{T}}{\mathrm{a}} \overrightarrow{\mathrm{b}}$ & 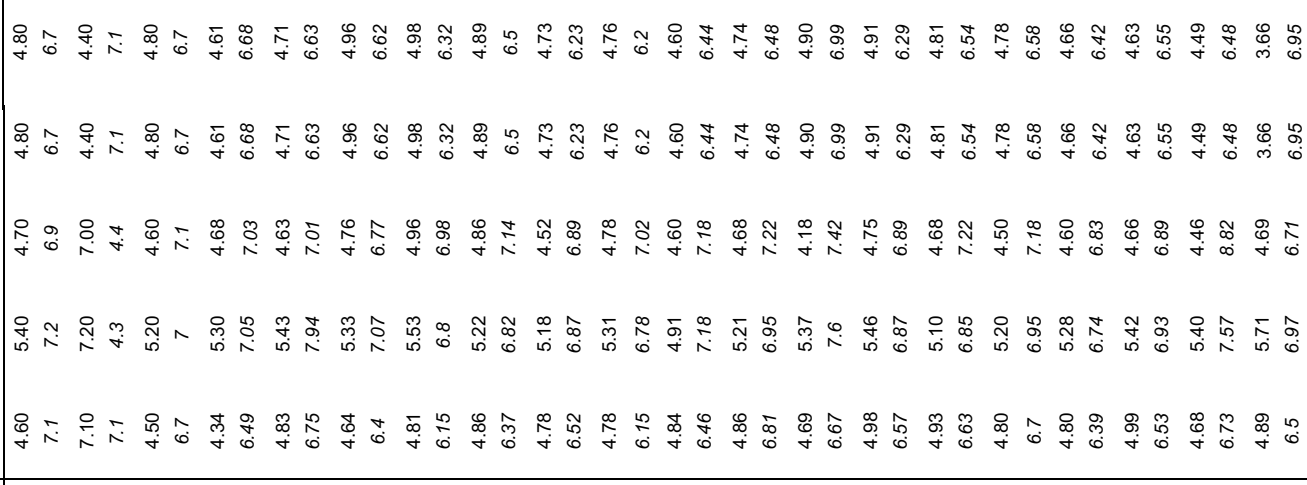 \\
\hline $\begin{array}{cc} & \vdots \\
\vdots & \\
0 & b \\
\infty & 0\end{array} \mid$ & 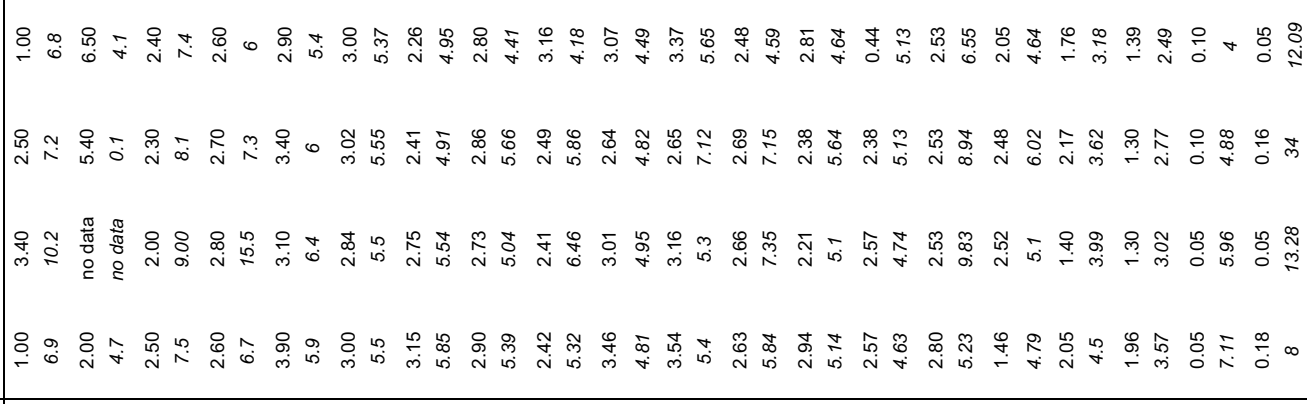 \\
\hline 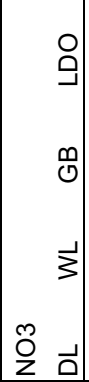 & 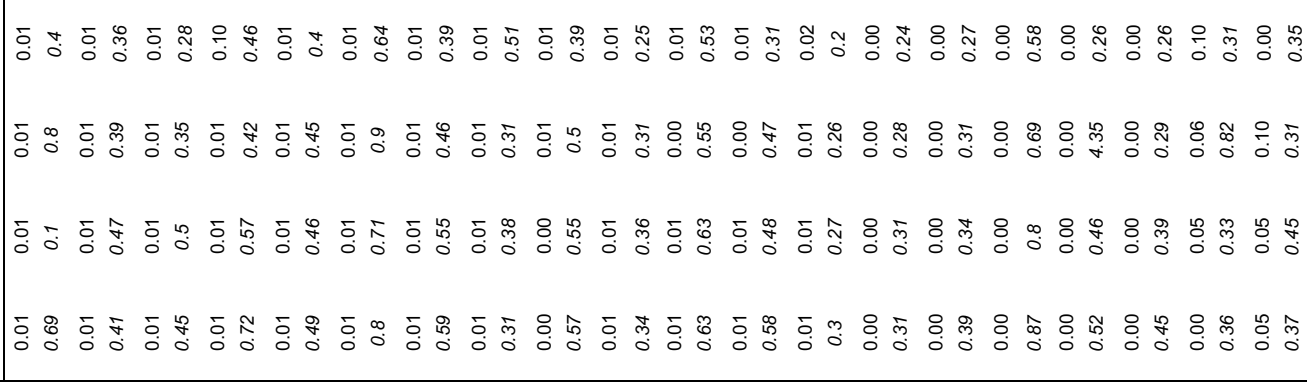 \\
\hline 이 & 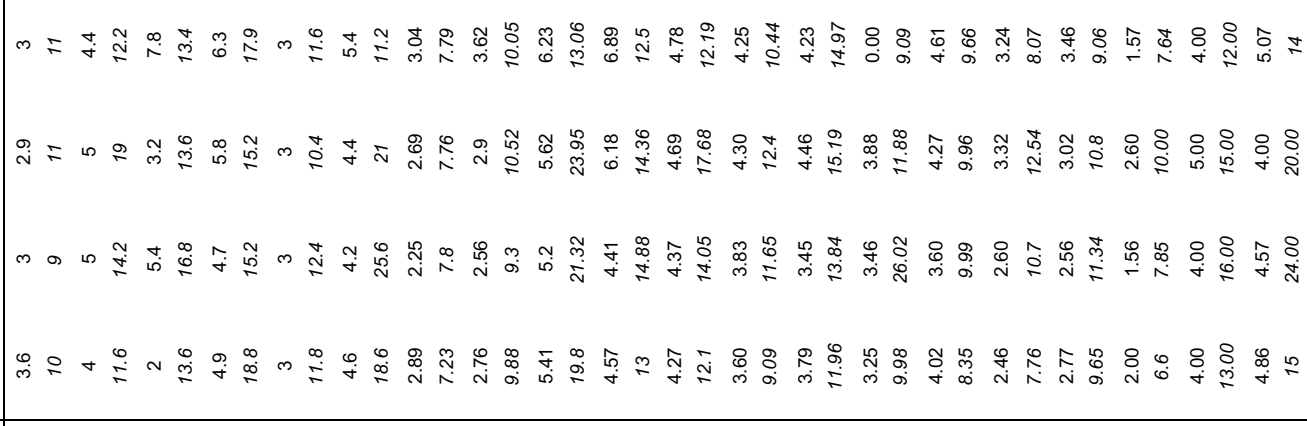 \\
\hline $\begin{array}{l}0 \\
0 \\
0 \\
0 \\
3 \\
3\end{array}$ & 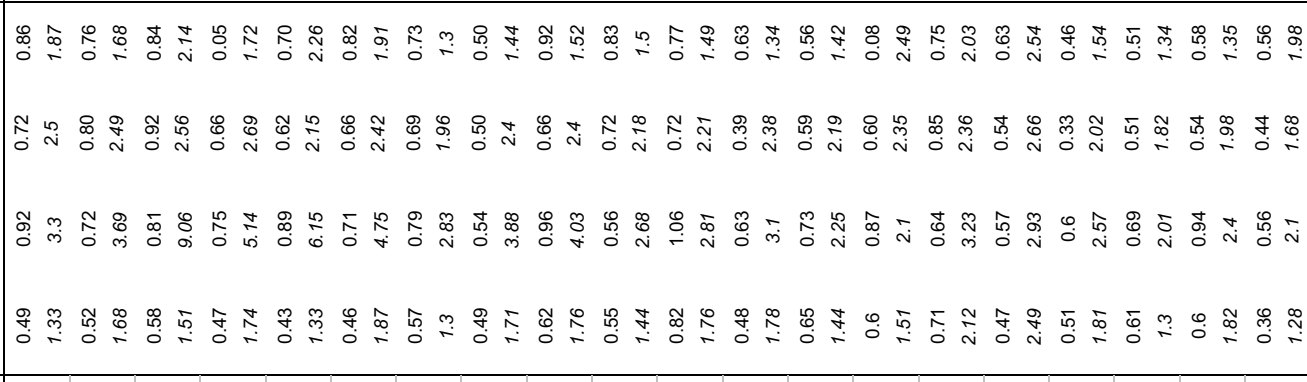 \\
\hline & 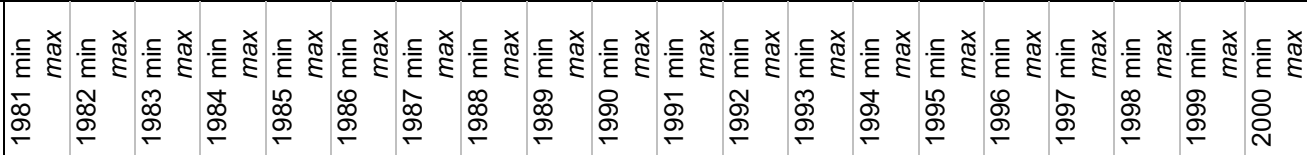 \\
\hline
\end{tabular}



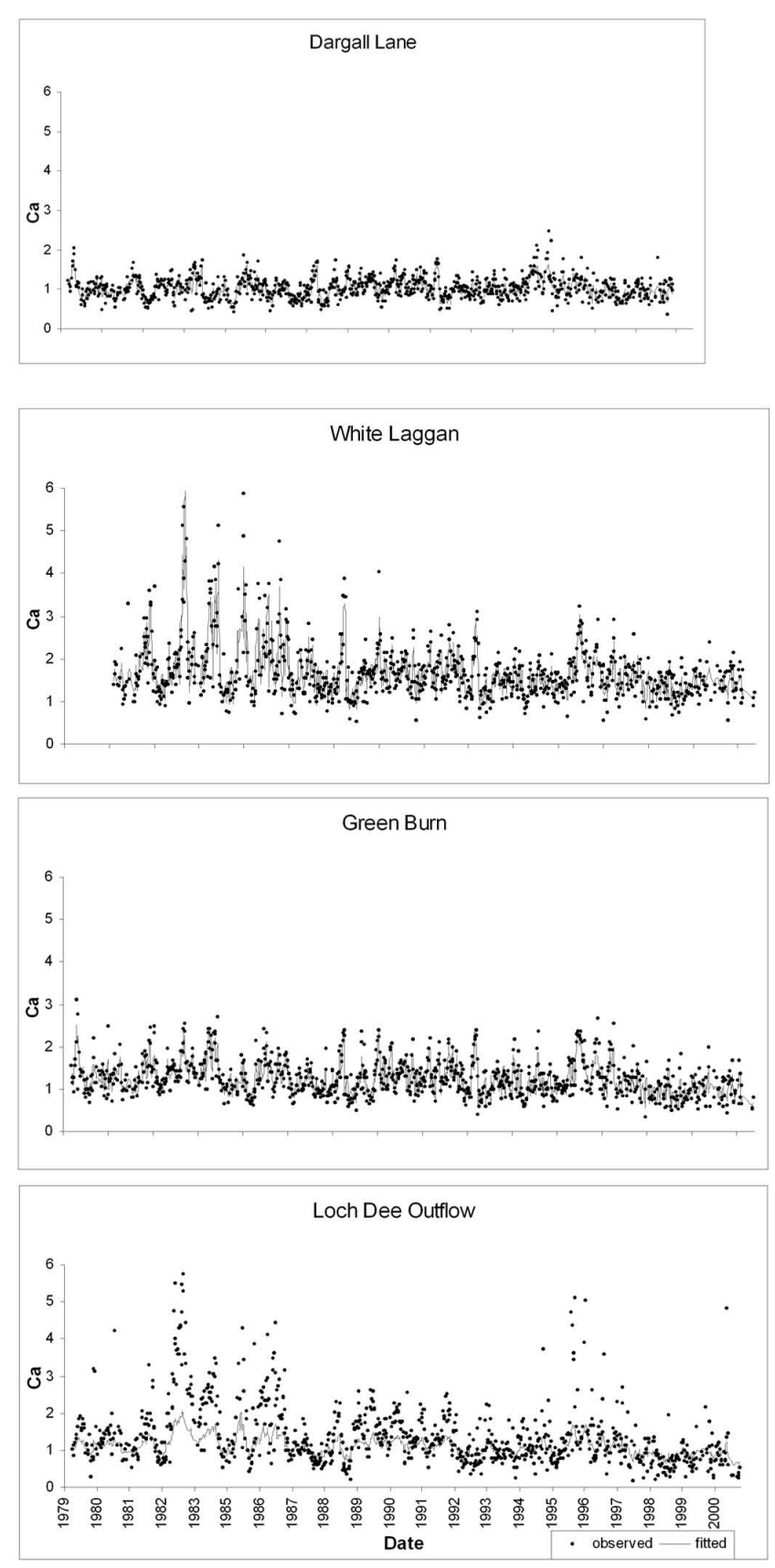

Fig. 4. Observed versus modelled calcium data for the three inlet streams and loch outflow.

concentrations, the most noticeable of these occurring in $1985 / 86$ and 1996. The same pattern occurs in all of the trend analyses. In contrast to the low flow data, the high flow record (Fig. 5b) shows no overall trend with time, although during the latter part of the record the Green Burn responds in a similar manner to the Dargall Lane. This contrasts markedly to the earlier part of the record. During these higher flow periods, the Loch outflow is clearly
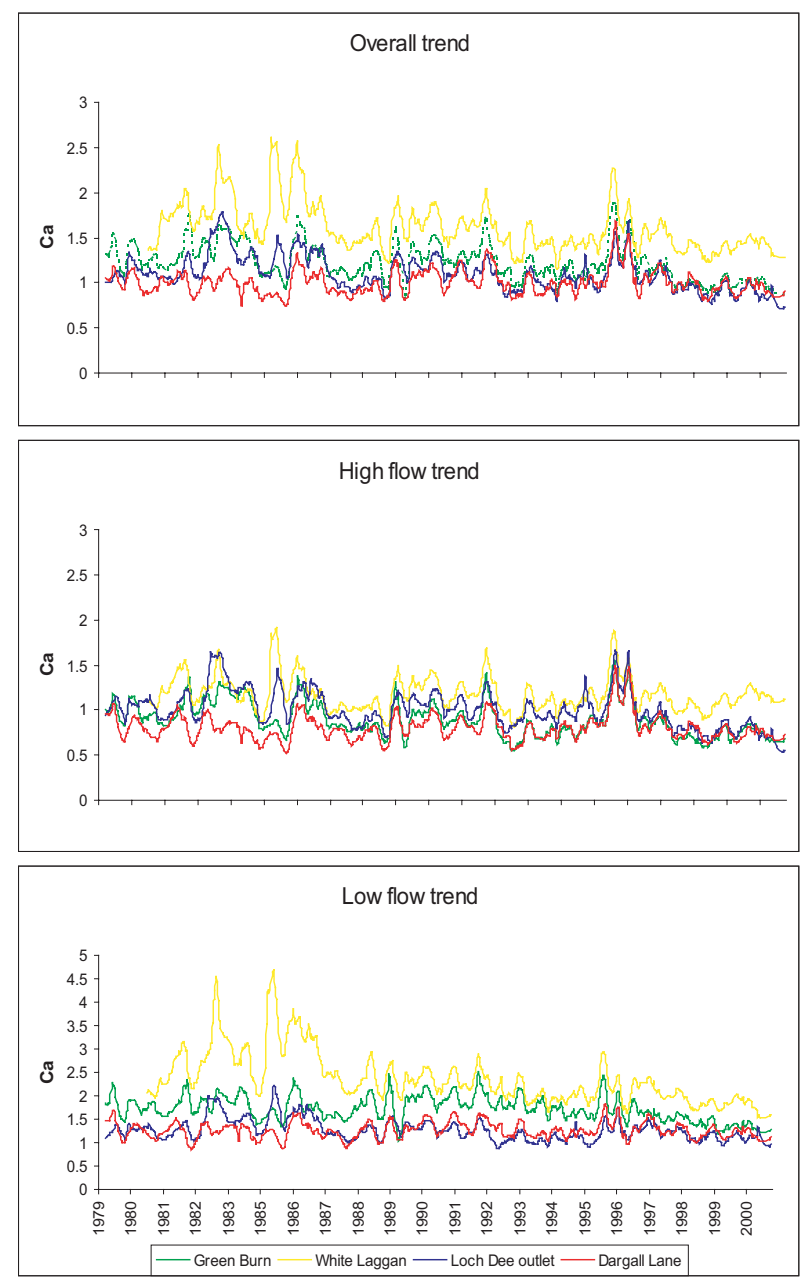

Fig. 5. Trend analysis for calcium using: a) all data b) high flow and c) low flow data (for the three inlet streams and loch outflow)

dominated by the calcium input from the largest subcatchment, the White Laggan.

\section{CHLORIDE}

Table 3 shows the difference between the concentrations of chloride at the four sampling points is relatively small, particularly in comparison to the annual differences. Concentrations of chloride in annual bulk deposition inputs vary three fold (Table 2) whilst stream concentrations can vary by $100 \%$ across the data record (Table 3 ). The data suggest that the highest mean surface water concentrations occurred in three periods: 1983-84, 1989-91 and 19992000. In terms of maximum concentrations, the years 1984 , 1986, 1989, 1991, 1999 and 2000 stand out (an additional response at the White Laggan in 1994 is thought to coincide with a fertiliser application, although this has not been possible to verify). The highest concentrations occur in the two forested catchments (Green Burn and White Laggan), 
Table 4. Summary of the trend analysis results indicating the variance (\%) the model accounts for due to: flow, season, trend and residual.

\begin{tabular}{|c|c|c|c|c|}
\hline & Flow & Season & Trend & Residual \\
\hline \multicolumn{5}{|l|}{ PH } \\
\hline Dargall Lane & 33 & 10 & 11 & 31 \\
\hline White Laggan & 37 & 11 & 7 & 29 \\
\hline Green Burn & 58 & 3 & 2 & 23 \\
\hline Loch Dee Outlet & 23 & 18 & 10 & 30 \\
\hline \multicolumn{5}{|l|}{$\mathrm{Ca}$} \\
\hline Dargall Lane & 27 & 5 & 23 & 25 \\
\hline White Laggan & 41 & 1 & 19 & 20 \\
\hline Green Burn & 38 & 1 & 24 & 20 \\
\hline Loch Dee Outlet & 9 & 4 & 46 & 20 \\
\hline \multicolumn{5}{|l|}{$\mathrm{Cl}$} \\
\hline Dargall Lane & 2 & 25 & 43 & 19 \\
\hline White Laggan & 4 & 32 & 45 & 11 \\
\hline Green Burn & 3 & 31 & 46 & 12 \\
\hline Loch Dee Outlet & 1 & 22 & 55 & 12 \\
\hline \multicolumn{5}{|l|}{ NO3 } \\
\hline Dargall Lane & 1 & 69 & 10 & 10 \\
\hline White Laggan & 3 & 68 & 14 & 11 \\
\hline Green Burn & 3 & 61 & 12 & 11 \\
\hline Loch Dee Outlet & 1 & 60 & 13 & 17 \\
\hline \multicolumn{5}{|l|}{ SO4 } \\
\hline Dargall Lane & 5 & 2 & 61 & 17 \\
\hline White Laggan & 4 & 2 & 80 & 10 \\
\hline Green Burn & 5 & 0 & 60 & 24 \\
\hline Loch Dee Outlet & 1 & 4 & 54 & 9 \\
\hline
\end{tabular}

the Green Burn having the highest mean concentration. Table 4 suggests the major variance in the data is due to seasonal and annual trend. The time series data in Fig. 6 illustrate a well-defined pattern with maximum concentrations occurring during the late winter/early spring months. This is confirmed in the variance data from the trend analysis (Table 4) which indicates a seasonal component and trend over the data record. The trend is dominated by the underlying events centred on the winters of 1984, 1991 and 1999-2000. There is no discernable difference in the trend observed in the sub-catchments or loch outflow. Analysis for low and high flows is not illustrated as it accounts for such a small amount of the variance (see Table 4).

\section{NITRATE}

Comparison of the annual concentration data in Table $3 \mathrm{a}$ suggests that mean concentrations are low across all of the monitoring sites although there are differences both between sites and between years. The maximum concentrations of nitrate occur during the years 1986, 1989 and 1996 but these annual data yield no information of a systematic basis to this variation. Table 4 shows that the trend in the data is overwhelmingly dominated by the seasonal differences. Figure 7 shows that minimum concentrations occurred during the summer when biological uptake is maximal and maximum concentrations occur in the winter when biological uptake is low. The trend analysis (Fig. 7e) suggests there is a difference between Dargall Lane and the loch outflow in comparison to the forested sub-catchments (White Laggan and Green Burn). The overall trend in the data apparently corresponds to the events noted for chloride.

\section{SULPHATE}

Table 2 shows that from the mid-1980s there has been a gradual decline in sulphate concentration in precipitation; similarly, from 1984, the surface waters illustrate a gradual decline in sulphate concentration (Table 3a, Fig. 8a-d). The unresolved issues regarding the quality of the sulphate data 

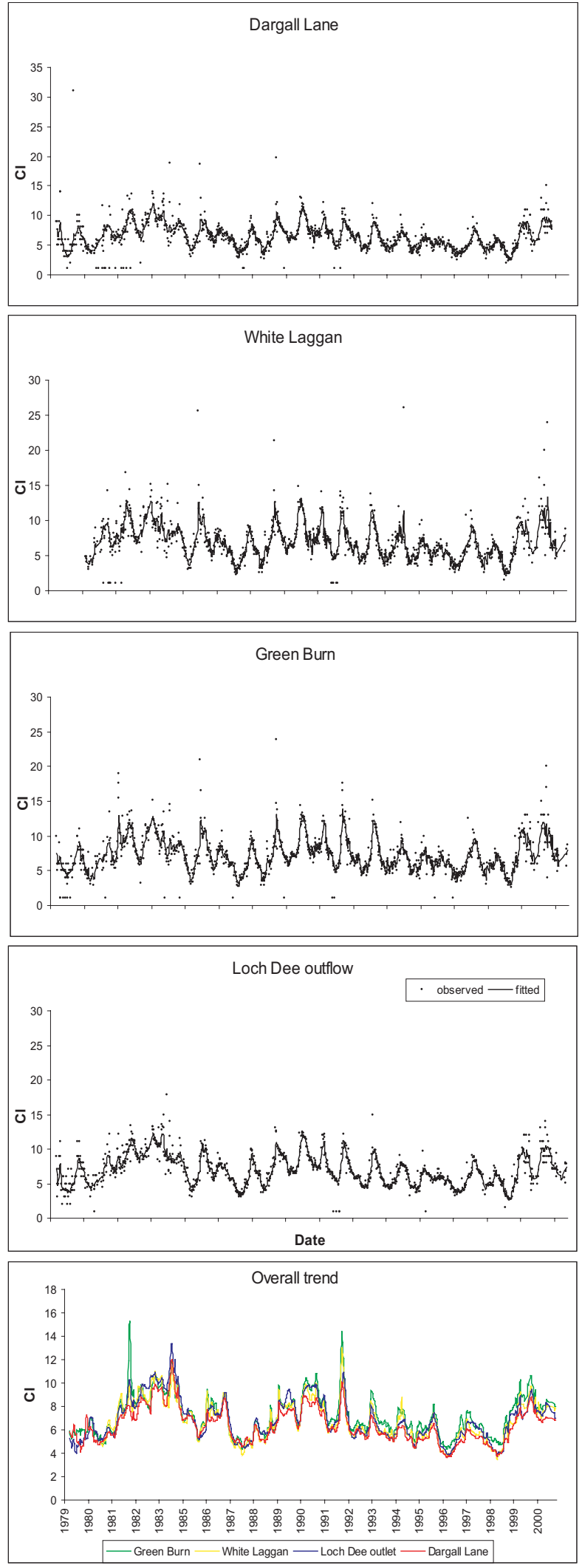

Fig. 6. Observed versus modelled chloride data (a-d) and trend analysis results (e) for the three inlet streams and loch outflow.
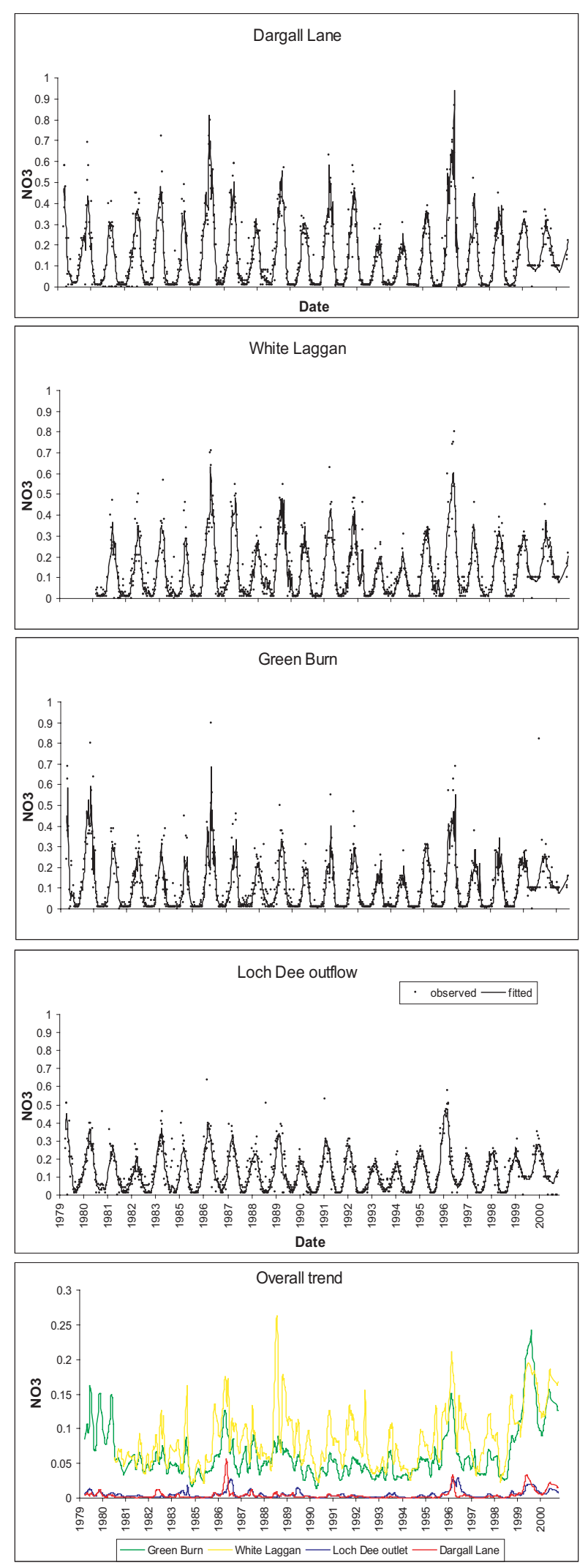

Fig. 7. Observed versus modelled nitrate data (a-d) and trend analysis results (e) for the three inlet streams and loch outflow. 

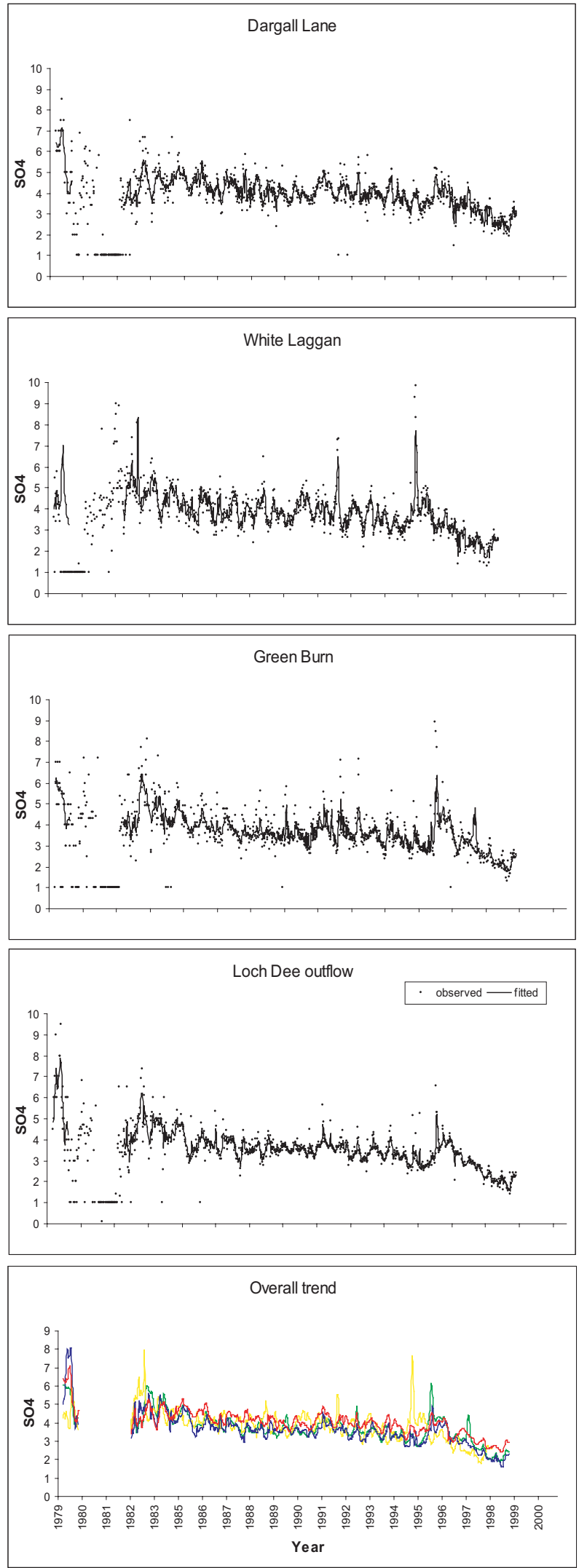

Fig. 8. Observed versus modelled sulphate data $(a-d)$ and trend analysis results (e) for the three inlet streams and loch outflow. at the beginning and end of the record are clear from the loch outflow data (Fig. 8d). The trend analysis shows the high percentage of variance in the modelled data that can be ascribed to the overall trend of the record. Figure $8 \mathrm{e}$ shows there is little difference between the sub-catchments and loch outflow. Whilst the decline in sulphate concentrations is evident over the period 1984 to 1994, it becomes more rapid after 1996 as that over the period 19842000 , there is a reduction in concentration of some $50 \%$.

\section{Discussion and conclusion}

The results have presented the salient features of weekly spot samples and modelled data that together describe the water quality at Loch Dee over a 20 year period. The data have been presented in terms of some of the key parameters of spatial and temporal trends between sub-catchments. Ideally, the analysis should have included alkalinity and acid neutralising capacity. Unfortunately, constraints on the data made it impossible to consider these determinands.

This discussion considers the relative role of atmospheric inputs, land management and other factors that interact to affect the water quality at Loch Dee. On the basis of the results presented, it is evident that both natural and pollutant sources of ions from the atmosphere influence water quality. There are four substantive issues concerning changes in water quality:

1. The trend over the existing data record, resulting from changes in deposition inputs

Two dominant aspects of atmospheric deposition influence the water quality in the Loch Dee catchments. The first is the influence of chloride and, specifically, 'sea-salt' laden storm episodes; detailed descriptions of the mechanisms and the short-term impacts of these episodes have been documented elsewhere (Langan, 1989; Neal and Kirchner, 2000). The influence of these storms is apparent in all of the water quality determinands considered, ranging from calcium through to nitrate. The present analysis shows that these episodes affect water quality for several years. To the authors' knowledge such longevity in the influence of the process has not been reported previously and provides an important insight into understanding the process and assessment of catchment responses to atmospheric deposition in regions subject to maritime conditions. Evans and Monteith (2002) suggested that the incidence of such events may be related to periods of high NAO index. A comparison of the winter months and a more generalised winter NAO index with the observed and trend data reported here showed a broadly similar seasonal pattern when 
examined but the similarity was not reproduced statistically. Secondly, the data record also shows a gradual decline in stream water sulphate concentrations. This is concurrent both in magnitude and timing with reductions in pollutant sulphur deposition inputs.

\section{Water quality changes associated with land-management and the modification of atmospheric inputs}

It is widely recognised that coniferous trees have a greater ability to capture atmospheric borne aerosols than short or low lying vegetation such as Calluna moorland. For both of the atmospherically derived ions considered, chloride and sulphate, it is interesting to note the highest peak concentrations occur in the forested streams. Similarly both the annual mean data and the time series data for sulphate suggest that there are significant differences between the sub-catchment responses. The decline is greatest in the Dargall Lane and least in the Green Burn. This may be attributed to the greater efficiency of trees in the Green Burn sub-catchment $(70 \%$ forest cover) in capturing atmospheric pollutants. Nitrate concentrations in the stream-water are also influenced strongly by the land uses in the subcatchment. This is illustrated by the very strong seasonal variation in concentration; negligible during the summer growing season (when there is a high biological demand) but which rise during the winter months when the vegetation is dormant and nitrate is flushed from the catchment soils.

\section{Land management practices}

The influence of land management, through the experimental liming programme, on the sub-catchment water quality is less clear. It could also be argued that the liming programme (Table 1) has led to the higher calcium concentrations of the White Laggan in comparison to the others. This is probably best observed in the early part of the data. Unfortunately the paucity of data, prior to the liming programme, precludes the analysis of the extent to which this factor may be contributing. However, it is likely that some of this difference is due to geological control. This could be in the form of an outcrop of base rich material in the greywacke/shale lithology in the upper part of the catchment. This point is emphasised by the similarity in the low flow $\mathrm{pH}$ record of White Laggan and Green Burn during the middle of the data record (1989-1995).

\section{Catchment hydrology}

Further differences in the variability of the water quality between the sub-catchments exist as a result of hydrological differences. Both calcium and $\mathrm{pH}$ are highly (negatively) correlated with flow. During low flows, higher calcium and $\mathrm{pH}$ water from buffered, longer resident shallow groundwaters feed the streams; during higher flows, an increasing proportion of the water in the stream is derived from the more acid, calcium-poor upper soil horizons. The comparison of the variability in these quantities indicates that, over the period of the data record, hydrological controls are important. The soils and topography of the Dargall Lane give rise to a damped hydrological response in which waters from the various soil horizons are well mixed and, consequently, the chemical variation with time is limited. Conversely in the Green Burn and White Laggan where forestry plough furrows permit the rapid transit of storm runoff, the difference between storm and base flow chemistry is more marked. For the loch outflow, the loch itself provides a large buffer, so that the chemical response of the outflow is damped in relation to concentrations that are hydrologically dependent.

The Loch Dee data provide a long record of the hydrochemistry of upland catchments with different landuses. The value of these records is their longevity and continuous nature. The interpretation of these data has been aided by the use of a simple generalised additive model that has identified the time-scales of trends and differences between sub-catchment responses. The analysis has identified the differing contributions of atmospheric deposition inputs (both natural and anthropogenic) and land use influences on the water quality. Of particular note is the substantial role of sea-salts in modifying longer term trends brought about by changing atmospheric pollutant inputs.

\section{Acknowledgement}

The authors gratefully acknowledge SNIFFER and the Scottish Executive Environment and Rural Affairs Department for funding this work. Thanks are also extended to the Loch Dee Project partners and sponsors, in particular the Forestry Commission and SEPA staff who have so diligently collected, analysed and recorded the data over the last twenty years

\section{References}

Burns, J.C., Coy, J.S., Tervet, D.J., Harriman, R., Morrison, B.R.S and Quine, C.P., 1984. The Loch Dee Project: a study of the ecological effects of acid precipitation and forest management on an upland catchment in south-west Scotland. Fish. Manage., 15, 145-167.

Crisp, D.T., 1966. Input and output of minerals for an area of pennine moorland: The importance of precipitation, drainage, peat erosion and animals. J. Appl. Ecol., 3, 327-348.

Cryer, D., 1976. The significance and variation of atmospheric nutrient inputs to small catchment systems, J. Hydrol., 29, 121137. 
Davies, T.D., Tranter, M., Wigington, P.J. and Eshleman, K.N., 1992. Acidic episodes in surface waters in Europe. J. Hydrol. 132, 25-69.

DEFRA, 2001. National Expert Group on Transboundary Air Pollution: Acidification, Eutrophication and Ground-Level Ozone in the UK. Report to Department for the Environment, Food and Rural Affairs, Ashdown House, London, UK. ISBN 1 870393619

Evans, C.D. and Monteith, D.T., 2002. Natural and anthropogenic changes in the chemistry of six UK mountain lakes 1988-2000. Water Air Soil Pollut.: Focus 2, 33-46.

Evans, C.D., Cullen, J.M., Alewell, C., Kopacek, J., Marchetto, A., Moldan, F., Prechtel, A., Rogora, M., Vesely, J. and Wright, R.F., 2001. Recovery from acidification in European surface waters. Hydrol. Earth Syst. Sci., 5, 283-297.

Farrell, E.P., 1995. Atmospheric deposition in maritime environments and its impact on terrestrial ecosystems. Water Air Soil Pollut., 85, 123-130.

Farley, D.A. and Werritty, A., 1989. Hydrochemical budgets for the Loch Dee experimental catchments, southwest Scotland. $J$. Hydrol., 109, 351-368.

Ferrier, R.C., Jenkins, A., Wright, R.F., Schopp, W. and Barth, H., 2001. Assesment and recovery of European surface waters from acidification 1970-2000: an introduction to the special issue. Hydrol. Earth Syst. Sci., 5, 274-282.

Ferrier, R.C, Wright, R.F., Jenkins, A. and Barth, H., 2003. Predicting recovery of acidified freshwaters in Europe and Canada: an introduction. Hydrol. Earth Syst. Sci., 7, 431-435.

Forestry Commission/Department of the Environment, 1991. Forests and Surface Water Acidification. Report of the Darlington Meeting 25-27 June 1990.

Fowler, D., Cape, J.N. and Unsworth, M.H., 1989. Deposition of atmospheric pollutants on forests. Phil. Trans. R. Soc. B., 324, 247-265.

Grieve, I.C., 1990. Variations in the chemical composition of the soil solution over a four year period at an upland site in S.W Scotland. Geoderma, 46, 351--362.

Harriman, R. and Morrison, B.R.S., 1982. Ecology of streams draining forested and non forested catchments in an area of central Scotland. Hydrobiologica, 88, 251--263.

Helliwell, R.C., Ferrier, R.C, Johnston, L., Goodwin, J. and Doughty, R., 2001. Land use influences on acidification and recovery of freshwaters in Galloway, S.W. Scotland. Hydrol. Earth Syst. Sci., 5, 451--458.

Hirst, D.J., 1998. Estimating trends in stream water quality with a time-varying flow relationship. Austrian J. Stats., 27, 39-48.

Hornung, M., Roda, F. and Langan, S.J., 1991. A review of small catchment studies in western Europe producing hydrochemical budgets. Air Pollution Research Report, 28. Commission of European Communities, Brussels.

Jenkins, A., Camarero, L., Cosby, B.J., Ferrier, R.C., Forsius, M., Helliwell, R.C., Kopacek, J., Majer, V., Moldan, F., Posch, M., Rogora, M., Schopp, W. and Wright, R.F., 2003. A modelling assessment of acidification and recovery of European surface waters. Hydrol. Earth Syst. Sci., 7, 447--455.

Langan, S.J., 1989. Sea-salt induced streamwater acidification. Hydrol. Process., 3, 25-41.

Langan, S.J. and Wilson, M.J., 1994. Critical loads of acid deposition on Scottish soils. Water Air Soil Pollut., 75, 177191.

Langan, S.J., Soulsby, C. and Neal, C., 2001. The environmental context for water quality variation in Scotland. Sci. Total Envir., 265, 7-14.
Lees, F.M., 1992. Water Chemistry and Hydrology of Loch Dee. Occasional publication, Solway River Purification Board, Dumfries, Scotland.

Miller, J.D. and Hirst, D.J., 1998. Trends in concentrations of solutes in an upland catchment in Scotland. Sci. Total Envir., 216, 77-88.

Moldan, B. and Cerny, J., 1994. Biogeochemistry of small catchments: A tool for environmental research. SCOPE report 51 John Wiley, Chichester, UK. ISBN 0-471-93723-1.

Neal, C., 2004. The water quality functioning of the upper River Severn, Plynlimon, mid Wales: issues of monitoring, process understanding and forestry. Hydrol. Earth Syst. Sci., 8, 521532.

Neal, C. and Kirchner, J.W., 2000. Sodium and chloride levels in rainfall, mist, streamwater and groundwater at the Plynlimon catchments, mid-Wales: inferences on hydrological and chemical controls. Hydrol. Earth Syst. Sci., 4, 295--310.

Neal, C., Reynolds, B., Wilkinson, R.J., Hill, T., Neal, M., Hill, S., and Harrow, M.L., 1998b. The impacts of conifer harvesting on runoff water quality: a regional survey for Wales. Hydrol. Earth Syst. Sci, 2, 323-344.

Neal, C., Hill, T., Hill, S. and Reynolds, B., 1997b. Acid neutralization capacity measurements in surface and ground waters in the Upper River Severn, Plynlimon: from hydrograph splitting to water flow pathways. Hydrol. Earth Syst. Sci., 1, 687-696.

Neal, C., Reynolds, B., Adamson, J.K., Stevens, P.A., Neal, M., Harrow, M.L. and Hill, S., 1998a. Analysis of the impacts of major anion variations on surface water acidity: case studies from Wales and Northern England. Hydrol. Earth Syst. Sci., 2, 303--322.

Neal, C., Wilkinson, R.J., Neal, M., Harrow, M.L., Wickham, H., Hill, L. and Morfitt, C., 1997a. The hydrochemistry of the headwaters of the River Severn, Plynlimon, Wales. Hydrol. Earth Syst. Sci., 1, 583-618.

Neal, C., Reynolds, B., Neal, M., Pugh, B., Hill, L. and Wickham, H., 2001. Long-term changes in the water quality of rainfall, cloud water and stream water for moorland, forested and clear felled catchments of Plynlimon, mid- Wales. Hydrol. Earth Syst. Sci., 5, 274--282.

Potts, J.M., Hirst, D., Miller, J.D., Edwards, A.C. and Elston, D.A., 2003. Comparison of trends in stream water quality. Hydrol. Process., 17, 2449--2462.

Reynolds, B. and Edwards, A., 1995. Factors influencing dissolved nitrogen concentrations and loadings in upland streams of the UK. Agr. Water Manage., 27, 18--202.

Robson, A.J. and Neal, C., 1996. Water quality trends at an upland site in Wales, UK, 1983-1993. Hydrol. Process, 10, 183-203.

SEPA, Scottish Environment Protection Agency, 2000. State of the Environment, SEPA, Erskine Court, Stirling, Scotland.

Skartveit, A., 1981. Relationships between precipitation chemistry, hydrology and runoff acidity. Nord. Hydrol., 11, 65-81.

Soulsby, C., Turnbull, D., Langan, S.J., Owen, R. and Hirst, D., 1997. Reversibility of stream acidification on the Cairngorm region of Scotland. J. Hydrol, 195, 291-311.

Tervet, D.J. and Harriman, R., 1988 Changes in $\mathrm{pH}$ and calcium after selective liming in the catchment of Loch Dee, a sensitive and rapid turnover loch in south-west Scotland. Aquacult. Fish. Manage., 19, 191-203.

Wright, R.F., Norton, S.A., Brakke, D.F. and Frogner, T., 1988. Experimental verification of episodic acidification of freshwaters by sea salts. Nature, 334, 422-424. 